\title{
Ocean acidification and high irradiance stimulate the photo-physiological fitness, growth and carbon production of the Antarctic cryptophyte Geminigera cryophila
}

\author{
Scarlett Trimborn ${ }^{1,2}$, Silke Thoms ${ }^{1}$, Pascal Karitter ${ }^{1}$, and Kai Bischof ${ }^{2}$ \\ ${ }^{1}$ EcoTrace, Biogeosciences section, Alfred Wegener Institute, 27568 Bremerhaven, Germany \\ ${ }^{2}$ Marine Botany, Department 2 Biology/Chemistry, University of Bremen, 28359 Bremen, Germany \\ Correspondence: Scarlett Trimborn (scarlett.trimborn@awi.de)
}

Received: 15 March 2019 - Discussion started: 26 March 2019

Revised: 10 May 2019 - Accepted: 15 May 2019 - Published: 7 August 2019

\begin{abstract}
Ecophysiological studies on Antarctic cryptophytes to assess whether climatic changes such as ocean acidification and enhanced stratification affect their growth in Antarctic coastal waters in the future are lacking so far. This is the first study that investigates the combined effects of the increasing availability of $p \mathrm{CO}_{2}(400$ and $1000 \mu \mathrm{atm})$ and irradiance $\left(20,200\right.$ and $500 \mu \mathrm{mol}$ photons $\left.\mathrm{m}^{-2} \mathrm{~s}^{-1}\right)$ on growth, elemental composition and photophysiology of the Antarctic cryptophyte Geminigera cryophila. Under ambient $p \mathrm{CO}_{2}$, this species was characterized by a pronounced sensitivity to increasing irradiance with complete growth inhibition at the highest light intensity. Interestingly, when grown under high $p \mathrm{CO}_{2}$ this negative light effect vanished, and it reached the highest rates of growth and particulate organic carbon production at the highest irradiance compared to the other tested experimental conditions. Our results for G. cryophila reveal beneficial effects of ocean acidification in conjunction with enhanced irradiance on growth and photosynthesis. Hence, cryptophytes such as $G$. cryophila may be potential winners of climate change, potentially thriving better in more stratified and acidic coastal waters and contributing in higher abundance to future phytoplankton assemblages of coastal Antarctic waters.
\end{abstract}

\section{Introduction}

Even though Antarctic coastal waters comprise a relatively small area relative to the open ocean, these waters are highly productive due to the constant supply of macronutrients and iron (Arrigo et al., 2008). Shelf waters adjacent to the western Antarctic Peninsula (WAP) are currently undergoing rapid physical changes, exhibiting more rapid warming rates than anywhere in Antarctica over the last decades (Ducklow et al., 2007, 2013). Rising air temperature resulted in shorter sea ice seasons (Smith and Stammerjohn, 2001) with contrasting effects on phytoplankton biomass, composition and productivity between the northern and southern WAP. For the latter, the earlier retreat of sea ice together with the observed increase in surface water temperature led to shallow water column stratification, which favored phytoplankton growth and productivity. In the northern part of the WAP on the other hand, the earlier disappearance of sea ice was associated with greater wind activities and more cloud formation. As a consequence, a deepening of the upper mixed layer was found, providing less favorable light conditions. Next to reduced chlorophyll $a$ accumulation (Montes-Hugo et al., 2009) and primary production (Moreau et al., 2015), a decline in large phytoplankton such as diatoms relative to the whole community was observed (Montes-Hugo et al., 2009; Rozema et al., 2017). Accordingly, a recurrent shift from diatoms to cryptophytes and small flagellates was reported for waters north of the WAP, with important implications for food web dynamics (Moline et al., 2004; Ducklow et al., 2007; MontesHugo et al., 2009; Mendes et al., 2017). The frequent occurrence of cryptophytes was previously reported after di- 
atom blooms (Moline and Prézelin, 1996) and was related to surface meltwater stratification (Moline et al., 2004). As a result of rising global air temperatures, surface water freshening is expected to shallow the upper water layer, exposing phytoplankton to higher light intensity (Moreau et al., 2015). Relative to diatoms and the prymnesiophyte Phaeocystis antarctica, cryptophytes were found to be the main contributors to biomass in stratified and warm WAP coastal waters potentially resulting from their high tolerance to withstand high irradiances (Mendes et al., 2017). Considering the lack in ecophysiological studies carried out with Antarctic ecologically relevant cryptophyte species it remains unclear as yet whether the projected climatic changes could promote cryptophyte growth in Antarctic coastal waters in the future. Hence, higher abundances of cryptophytes could have important implications for the biogeochemistry of these waters, as they are considered to be inefficient vectors of carbon and thus could reduce the efficiency of the biological carbon pump.

Light availability strongly influences the rate of growth and carbon fixation of phytoplankton (Falkowski and Raven, 2007). With increasing irradiance, Antarctic phytoplankton species exhibited increased growth and carbon fixation, but only until photosynthesis was saturated (Fiala and Oriol, 1990; Heiden et al., 2016). When exposed to excessive radiation, phytoplankton cells can become photo-inhibited and even damaged (Falkowski and Raven, 2007). Cryptophytes are exceptional among eukaryotic microalgae as, similar to diatoms, they contain chlorophyll $a / c$ proteins, the carotenoid alloxanthin and phycobiliproteins homologous to red algal phycobiliproteins (Gould et al., 2008). This pigment composition allows cryptophytes to cope well under limited irradiance. Unlike diatoms and prymnesiophytes, cryptophytes have no photo-protective de-epoxidation-epoxidation cycling of xanthophyll pigments (e.g., diadinoxanthin, diatoxanthin), instead they rely on chlorophyll $a / c$ proteins, which dissipate excess light energy, as another type of nonphotochemical quenching (NPQ; Funk et al., 2011; Kana et al., 2012). While laboratory studies so far have mainly concentrated on disentangling the physiological response of Southern Ocean key species of diatom and prymnesiophytes to different environmental factors, almost nothing is known on Antarctic cryptophytes. Apart from field studies (Moline et al., 2004; Ducklow et al., 2007; Montes-Hugo et al., 2009), almost nothing is known on how climate change could influence the ecophysiology of Antarctic cryptophytes. Due to the increased solubility of $\mathrm{CO}_{2}$ in cold water, ocean acidification (OA) is anticipated to strongly affect polar waters (Orr et al., 2005; Pachauri et al., 2014). For various Antarctic diatoms and the prymnesiophyte $P$. antarctica, growth and/or carbon fixation remained unaltered by OA alone (Riebesell et al., 1993; Boelen et al., 2011; Hoogstraten et al., 2012; Trimborn et al., 2013; Hoppe et al., 2015; Heiden et al., 2016). Recent studies suggest that Southern Ocean diatoms are more prone to $\mathrm{OA}$ especially in conjunction with high light than the prymnesiophyte Phaeocystis antarctica (Feng et al., 2010; Trimborn et al., 2017a, b; Beszteri et al., 2018; Heiden et al., 2018, 2019; Koch et al., 2018). The response of cryptophytes to OA is hitherto almost unexplored. The few studies on temperate phytoplankton communities suggest that cryptophytes were not affected by OA (Schulz et al., 2017), even when exposed in combination with increased ultraviolet radiation (Domingues et al., 2014) or warming (Sommer et al., 2015). Similarly, no discernible OA effect on cryptophyte abundance was found in subantarctic (Donahue et al., 2019) and Antarctic (Young et al., 2015) natural phytoplankton communities composed of diatoms, cryptophytes and Phaeocystis spp.

Based on previous studies on the single effects of light or $\mathrm{CO}_{2}$ alone, we hypothesize that cryptophytes are able to cope well with OA and high light conditions. Due to the limited information available on Antarctic cryptophyte physiology, this study assessed OA effects and their interaction with increasing irradiance on the physiology of the Antarctic cryptophyte Geminigera cryophila. To this end, G. cryophila was grown under two $p \mathrm{CO}_{2}$ levels (400 and $\left.1000 \mu \mathrm{atm}\right)$ in combination with three irradiance levels $(20,200$ and $500 \mu \mathrm{mol}$ photons $\mathrm{m}^{-2} \mathrm{~s}^{-1}$ ) and their interactive effects on growth, elemental composition and photo-physiology were assessed.

\section{Material and methods}

\subsection{Culture conditions}

Triplicate semicontinuous cultures of the Antarctic cryptophyte Geminigera cryophila (CCMP 2564) were grown in exponential phase at $2{ }^{\circ} \mathrm{C}$ in sterile-filtered $(0.2 \mu \mathrm{m})$ Antarctic seawater (salinity 30.03 ). This seawater was enriched with phosphate (final concentration of $100 \mu \mathrm{mol} \mathrm{L}^{-1}$ ), nitrate (final concentration of $\left.6.25 \mu \mathrm{mol} \mathrm{L}^{-1}\right)(\mathrm{N}: \mathrm{P}$ ratio of $16: 1$; Redfield, 1958), and trace metals and vitamins according to F/2 medium (Guillard and Ryther, 1962). G. cryophila cells were grown under a $16 \mathrm{~h}$ light and $8 \mathrm{~h}$ dark cycle at three constant light intensities $(L L=20, M L=200$ and $\mathrm{HL}=500 \mu \mathrm{mol}$ photons $\mathrm{m}^{-2} \mathrm{~s}^{-1}: \mathrm{LL}-$ low light; $\mathrm{ML}-$ medium light; HL - high light) using light-emitting diode (LED) lamps (SolarStinger LED SunStrip Marine Daylight, Econlux). Light intensities were adjusted using a LI-1400 data logger (Li-Cor, Lincoln, NE, USA) with a $4 \pi$ sensor (Walz, Effeltrich, Germany). The three light treatments were further combined with two $\mathrm{CO}_{2}$ partial pressures $\left(p \mathrm{CO}_{2}\right)$ of 400 (ambient $p \mathrm{CO}_{2}$ treatment) or $1000 \mu \mathrm{atm}(\mathrm{OA}$ treatment, Table 1). All $p \mathrm{CO}_{2}$ treatments and the respective dilution media were continuously and gently bubbled through a frit with humidified air of the two $p \mathrm{CO}_{2}$ levels, which were generated from $\mathrm{CO}_{2}$-free air $\left(<1 \mathrm{ppmv} \mathrm{CO}_{2}\right.$; Dominick Hunter, Kaarst, Germany) and pure $\mathrm{CO}_{2}$ (Air Liquide Deutschland ltd., Düsseldorf, Germany) with a gas flow 
controller (CGM 2000, MCZ Umwelttechnik, Bad Nauheim, Germany). The $\mathrm{CO}_{2}$ gas mixtures were regularly monitored with a nondispersive infrared analyzer system (LI6252; LiCor Biosciences) calibrated with $\mathrm{CO}_{2}$-free air and purchased gas mixtures of $150 \pm 10$ and $1000 \pm 20 \mathrm{ppmv} \mathrm{CO}_{2}$ (Air Liquide Deutschland). Dilutions with the corresponding acclimation media ensured that the $\mathrm{pH}$ level remained constant ( \pm 0.07 units, Table 1) and that the cells stayed in the exponential growth phase. G. cryophila cells were acclimated to the matrix of three light intensities $(\mathrm{LL}=20, \mathrm{ML}=200$ and $\mathrm{HL}=500 \mu \mathrm{mol}$ photons $\mathrm{m}^{-2} \mathrm{~s}^{-1}$ ) and two $p \mathrm{CO}_{2}$ levels (ambient $=400$ and $\mathrm{OA}=1000 \mu \mathrm{atm}$ ) for at least 2 weeks prior to the start of the main experiment. Despite several attempts, G. cryophila did not grow at ambient $p \mathrm{CO}_{2}$ in conjunction with HL. For the main experiments, cells grew in exponential phase and final sampling took place between 7280 and 17161 cells $\mathrm{mL}^{-1}$.

\subsection{Seawater carbonate chemistry}

The $\mathrm{pH}$ of the different cultures and the culture medium was measured every other day and on the final sampling day using a pH ion meter ( $\mathrm{pH}$ meter 827, Metrohm), calibrated (threepoint calibration) with National Institute of Standards and Technology-certified buffer systems. The $\mathrm{pH}$ remained constant at $8.13 \pm 0.07$ and $7.82 \pm 0.06$ for the ambient $p \mathrm{CO}_{2}$ and OA treatments, respectively (Table 1). Dissolved inorganic carbon (DIC) samples were sterile-filtered $(0.2 \mu \mathrm{m})$ and stored at $4{ }^{\circ} \mathrm{C}$ in $5 \mathrm{~mL}$ gastight borosilicate bottles without headspace until analysis. DIC was measured colorimetrically in duplicates with a QuAAtro autoanalyzer (Seal Analytical, Stoll et al., 2001). The carbonate system was calculated based on DIC, $\mathrm{pH}$, silicate $\left(97 \mu \mathrm{mol} \mathrm{kg}^{-1}\right)$, phosphate $\left(6.1 \mu \mathrm{mol} \mathrm{kg}{ }^{-1}\right)$, temperature $\left(2.0^{\circ} \mathrm{C}\right)$ and salinity $(30.03)$ using the CO2Sys program (results shown in Table 1; Pierrot et al., 2006) choosing the equilibrium constant of Mehrbach et al. (1973) refitted by Dickson and Millero (1987).

\subsection{Growth, elemental stoichiometry and composition}

Cell count samples of every G. cryophila treatment were taken on a daily basis at the same time of day and were determined immediately after sampling using a Coulter Multisizer III (Beckmann-Coulter, Fullerton, USA). Cell-specific growth rate $\left(\mu\right.$, unit $\left.\mathrm{d}^{-1}\right)$ was calculated as

$\mu=\left(\ln N_{\text {fin }}-\ln N_{0}\right) / \Delta t$,

where $N_{0}$ and $N_{\text {fin }}$ denote the cell concentrations at the beginning and the end of the experiments, respectively, and $\Delta t$ is the corresponding duration of incubation in days.

Particulate organic carbon (POC) and particulate organic nitrogen (PON) were measured after filtration onto precombusted $\left(12 \mathrm{~h}, 500^{\circ} \mathrm{C}\right)$ glass fiber filters $(\mathrm{GF} / \mathrm{F}$, pore size $\sim$ $0.6 \mu \mathrm{m}$, Whatman). Filters were stored at $-20^{\circ} \mathrm{C}$ and dried for $>12 \mathrm{~h}$ at $64^{\circ} \mathrm{C}$ prior to sample preparation. Analysis was performed using a Euro Vector CHNS-O elemental analyzer (Euro Elemental Analyzer 3000, HEKAtech GmbH, Wegberg, Germany). Contents of POC and PON were corrected for blank measurements and normalized to filtered volume and cell densities to yield cellular quotas. Production rates of POC and PON were calculated by multiplication of the cellular quota with the specific growth rate of the respective treatment.

\subsection{Chlorophyll $a$ fluorescence}

The efficiency of photochemistry in photosystem II (PSII) was assessed in all treatments using a fast repetition rate fluorometer (FRRf; FastOcean PTX; Chelsea Technologies Group Ltd., West Molesey, United Kingdom) in combination with a FastAct Laboratory system (Chelsea Technologies Group Ltd., West Molesey, United Kingdom). Cells of the respective treatment were dark-acclimated for $10 \mathrm{~min}$, before minimum chlorophyll $a$ (Chl $a$ ) fluorescence $\left(F_{\mathrm{o}}\right)$ was recorded. Subsequently, a single turnover flashlet $(1.2 \times$ $10^{22}$ photons $\mathrm{m}^{-2} \mathrm{~s}^{-1}$, wavelength $450 \mathrm{~nm}$ ) was applied to cumulatively saturate photosystem II (PSII), i.e., a single photochemical turnover (Kolber et al., 1998). The single turnover saturation phase comprised 100 flashlets on a $2 \mu \mathrm{s}$ pitch and was followed by a relaxation phase comprising 40 flashlets on a $50 \mu$ s pitch. This sequence was repeated 24 times within each acquisition. The saturation phase of the single turnover acquisition was fitted according to Kolber et al. (1998). From this measurement, the minimum $\left(F_{\mathrm{O}}\right)$ and maximum $\left(F_{\mathrm{m}}\right)$ Chl $a$ fluorescence was determined. Using these two parameters, the dark-adapted maximum PSII quantum yield $\left(F_{\mathrm{v}} / F_{\mathrm{m}}\right)$ was calculated according to the equation $\left(F_{\mathrm{m}}-F_{\mathrm{o}}\right) / F_{\mathrm{m}}$. During the fluorescence light curve (FLC), cells were exposed for $5 \mathrm{~min}$ to eight actinic light levels ranging from 35 to $1324 \mu$ mol photons $\mathrm{m}^{-2} \mathrm{~s}^{-1}$. From these measurements, the light-adapted minimum $\left(F^{\prime}\right)$ and maximum $\left(F_{\mathrm{m}}^{\prime}\right)$ fluorescence of the single turnover acquisition was estimated. The effective PSII quantum yield under ambient light $\left(F_{\mathrm{q}}^{\prime} / F_{\mathrm{m}}^{\prime}\right)$ was derived according to the equation $\left(F_{\mathrm{m}}^{\prime}-F^{\prime}\right) / F_{\mathrm{m}}^{\prime}$ (Genty et al., 1989). From this curve, absolute electron transport rates (ETRs, $\mathrm{e}^{-} \mathrm{PSII}^{-1} \mathrm{~s}^{-1}$ ) were calculated following Suggett et al. (2004, 2009):

$\mathrm{ETR}=\sigma_{\mathrm{PSII}} \times\left(F_{\mathrm{q}}^{\prime} / F_{\mathrm{m}}^{\prime} / F_{\mathrm{v}} / F_{\mathrm{m}}\right) \times E$,

where $\sigma_{\mathrm{PSII}}$ is the functional absorption cross section of PSII photochemistry and $E$ denotes the applied instantaneous irradiance (photons $\mathrm{m}^{-2} \mathrm{~s}^{-1}$ ). Light-use characteristics were analyzed by fitting irradiance-dependent ETRs according to Ralph and Gademann (2005), including maximum ETR $\left(\mathrm{ETR}_{\max }\right)$, minimum saturating irradiance $\left(I_{k}\right)$ and maximum light utilization efficiency $(\alpha)$. Using the Stern-Volmer equation, NPQ of chlorophyll $a$ fluorescence was calculated as $F_{\mathrm{m}} / F_{\mathrm{m}}^{\prime}-1$. From the single turnover measurement of darkadapted cells, $\sigma_{\text {PSII }}$, the energy transfer between PSII units (i.e., connectivity, $P$ ), the re-oxidation of the electron accep- 
Table 1. Partial pressures of $\mathrm{CO}_{2}\left(p \mathrm{CO}_{2}\right)$ for the ambient and ocean acidification $(\mathrm{OA})$ treatments were calculated from measured $\mathrm{pH}$, concentrations of dissolved inorganic carbon (DIC), silicate and phosphate, temperature, and salinity using the CO2Sys program (Pierrot et al., 2006). For all parameters, values are given for the abiotic control bottles (abiotic, bubbled seawater without cells) and the culture bottles at the end of the experiment (biotic). Different letters indicate significant differences between treatments $(p<0.05)$. Values represent the means $\pm \mathrm{SD}(n=3)$.

\begin{tabular}{|c|c|c|c|c|c|c|}
\hline \multirow[t]{2}{*}{$\begin{array}{l}\text { Target } p \mathrm{CO}_{2} \\
(\mu \mathrm{tm})\end{array}$} & \multicolumn{2}{|c|}{$\begin{array}{l}p \mathrm{CO}_{2} \\
(\mu \mathrm{atm})\end{array}$} & \multicolumn{2}{|c|}{$\begin{array}{c}\mathrm{pH} \\
(\mathrm{NBS})\end{array}$} & \multicolumn{2}{|c|}{$\begin{array}{c}\text { DIC } \\
\left(\mu \mathrm{mol} \mathrm{kg}^{-1}\right)\end{array}$} \\
\hline & abiotic & biotic & abiotic & biotic & abiotic & biotic \\
\hline Ambient $p \mathrm{CO}_{2}, 400$ & $372 \pm 18^{\mathrm{a}}$ & $398 \pm 66^{\mathrm{a}}$ & $8.14 \pm 0.02^{\mathrm{a}}$ & $8.13 \pm 0.07^{\mathrm{a}}$ & $2024 \pm 7^{\mathrm{a}}$ & $2062 \pm 12^{b}$ \\
\hline OA, 1000 & $986 \pm 42^{\mathrm{b}}$ & $865 \pm 120^{\mathrm{b}}$ & $7.75 \pm 0.02^{\mathrm{b}}$ & $7.82 \pm 0.06^{\mathrm{b}}$ & $2160 \pm 7^{c}$ & $2195 \pm 16^{\mathrm{d}}$ \\
\hline
\end{tabular}

tor $Q_{\mathrm{a}}\left(\tau_{Q_{\mathrm{a}}}\right)$ and the concentration of functional photosystem II reaction centers ([RII]) were assessed from iterative algorithms for induction (Kolber et al., 1998) and relaxation phase (Oxborough et al., 2012). [RII] represents an estimator for the content of PSII in the sample and was calculated according to the following equation:

$[\mathrm{RII}]=\left(F_{\mathrm{o}} / \sigma_{\mathrm{PSII}}\right) \times\left(K_{R} / E_{\mathrm{LED}}\right)$,

where $K_{R}$ is an instrument-specific constant and $E_{\mathrm{LED}}$ is the photon flux from the FRRf measuring LEDs. After the completion of the FLC, an additional dark-adaptation period of 10 min was applied, followed by a single turnover flashlet to check for recovery of PSII. Using the $F_{\mathrm{v}} / F_{\mathrm{m}}$ measured before and after the FLC, the yield recovery was calculated and given as the percentage of the initial $F_{\mathrm{v}} / F_{\mathrm{m}}$ (before the FLC). All measurements $(n=3)$ were conducted at the growth temperature of $2^{\circ} \mathrm{C}$.

\subsection{Pigments}

Samples for the determination of pigment concentration were filtered onto GF/F filters and immediately frozen at $-80^{\circ} \mathrm{C}$ until further analysis. Pigments samples were homogenized and extracted in $90 \%$ acetone for $24 \mathrm{~h}$ at $4{ }^{\circ} \mathrm{C}$ in the dark. After centrifugation $\left(5 \mathrm{~min}, 4^{\circ} \mathrm{C}, 13000 \mathrm{rpm}\right)$ and filtration through a $0.45 \mu \mathrm{m}$ pore size nylon syringe filter $\left(\right.$ Nalgene ${ }^{\circledR}$, Nalge Nunc International, Rochester, NY, USA), concentrations of chlorophyll $a$ and $c_{2}$ (Chl $a$ and $c_{2}$ ), and alloxanthin (Allo) were determined by reversed phase highperformance liquid chromatography (HPLC). The analysis was performed on a LaChromElite ${ }^{\circledR}$ system equipped with a chilled autosampler L-2200 and a DAD detector L-2450 (VWR-Hitachi International GmbH, Darmstadt, Germany). A Spherisorb ${ }^{\circledR}$ ODS-2 column $(25 \mathrm{~cm} \times 4.6 \mathrm{~mm}, 5 \mu \mathrm{m}$ particle size; Waters, Milford, MA, USA) with a LiChropher ${ }^{\circledR}$ 100-RP-18 guard cartridge was used for the separation of pigments, applying a gradient according to Wright et al. (1991). Peaks were detected at $440 \mathrm{~nm}$ and identified as well as quantified by co-chromatography with standards for Allo, Chl $a$ and $c_{2}$ (DHI Lab Products, Hørsholm, Denmark) using the software EZChrom Elite ver. 3.1.3. (Agilent Tech- nologies, Santa Clara, CA, USA). Pigment contents were normalized to filtered volume and cell densities to yield cellular quotas.

\subsection{Statistics}

Combined effects of the two $p \mathrm{CO}_{2}$ (ambient and OA) and light (LL, ML and HL) treatments on all experimental parameters were statistically analyzed using two-way analyses of variance (ANOVAs) with Bonferroni's multiple comparison post tests. To test for significant differences between light treatments of the OA-grown cells of G. cryophila cells oneway ANOVAs with additional Bonferroni's multiple comparison post tests were applied. All statistical analyses were performed using the program GraphPad Prism (Version 5.00 for Windows, Graph Pad Software, San Diego California, USA), and the significance testing was done at the $p<0.05$ level.

\section{Results}

\subsection{Seawater carbonate chemistry}

The two target $p \mathrm{CO}_{2}$ levels of 400 and $1000 \mu$ atm were successfully achieved for abiotic control (abiotic, bubbled seawater without cells) and culture bottles (biotic, one-way ANOVA: $p<0.0001$, Table 1). As the $p \mathrm{CO}_{2}$ of the abiotic control and culture bottles of the same $p \mathrm{CO}_{2}$ treatment were similar, this indicates that final cell numbers of G. cryophila did not alter the $p \mathrm{CO}_{2}$ of the culture bottles relative to the culture medium. Similar trends as for the $p \mathrm{CO}_{2}$ were also apparent for the measured $\mathrm{pH}$ values, which yielded $8.13 \pm 0.07$ and 7.82 \pm 0.06 in the culture bottles of the ambient and OA treatments, respectively (Table 1). While DIC concentrations were significantly enhanced for OA relative to the ambient $p \mathrm{CO}_{2}$ treatments (one-way ANOVA: $p<0.0001$ ), they also significantly differed between abiotic control (abiotic, bubbled seawater without cells) and culture bottles (biotic, Table 1). 


\subsection{Growth, elemental stoichiometry and composition}

Growth rates were significantly affected by light (two-way ANOVA: $p<0.01$ ) but not by OA or the interaction of both factors (Fig. 1a). In response to increasing irradiance, growth rates of cells grown under ambient $p \mathrm{CO}_{2}$ remained unchanged between LL and ML but were negatively influenced by HL as they were unable to grow. Under OA, however, growth rates significantly increased between LL and ML by $89 \%$ (post hoc: $p<0.05$ ) and between ML and HL by $32 \%$ (post hoc: $p<0.05$ ). Irrespective of changes in irradiance, $p \mathrm{CO}_{2}$ or their combination, cellular POC contents did not change (Fig. 1b). Daily POC production rates, were, however, significantly altered by increasing irradiance (twoway ANOVA: $p<0.01$ ) but not by OA or the interaction of both factors (Fig. 1c). While increasing light intensity did not affect POC production rates of the ambient $p \mathrm{CO}_{2}$ treatments, there was a significant OA-dependent enhancement of $69 \%$ between LL and ML (post hoc: $p<0.01$ ) and of $39 \%$ between ML and HL (post hoc: $p<0.05$ ). Molar $\mathrm{C}: \mathrm{N}$ ratios were only significantly influenced by the interaction of both factors together (two-way ANOVA: $p<0.01$; Fig. 1d). From LL to ML C : N ratios did not change for both $p \mathrm{CO}_{2}$ treatments, whereas from ML to HL the ratio declined by $12 \%$ for the OA treatment (one-way ANOVA: $p<0.05$ ). In response to increasing $p \mathrm{CO}_{2}, \mathrm{C}: \mathrm{N}$ decreased by $10 \%$ when grown under LL (post hoc: $p<0.05$ ) but remained unaltered at ML.

\subsection{Pigments}

For all $p \mathrm{CO}_{2}$ treatments, cellular concentrations of the measured pigments (Allo, Chl $a$ and $c_{2}$ ) showed a strong and significant decline between LL and ML (two-way ANOVA: $p<0.0001$, Table 2). Between ML and HL, however, different effects were seen, with a significant enhancement for Chl $a$ (post hoc: $p<0.01$ ) and Allo (post hoc: $p<0.01$ ) and no effect for $\mathrm{Chl} c_{2}$. Increasing $p \mathrm{CO}_{2}$ had generally no effect on cellular pigment quotas (Allo, Chl $a$ and $c_{2}$ ) except for the Allo quotas of the LL treatments, which displayed a significant OA-dependent decline of $26 \%$ (post hoc: $p<0.01$ ). A significant interaction between light and $\mathrm{CO}_{2}$ was only found for Allo quotas (two-way ANOVA: $p<0.05$ ).

\subsection{Chlorophyll $a$ fluorescence}

The dark-adapted maximum quantum yield of PSII $\left(F_{\mathrm{v}} / F_{\mathrm{m}}\right)$ was strongly influenced by irradiance (two-way ANOVA: $p<0.0001$ ) and $\mathrm{CO}_{2}$ (two-way ANOVA: $p=0.0012$ ) and their interaction (two-way ANOVA: $p<0.05$; Fig. 2a). With increasing irradiance $F_{\mathrm{v}} / F_{\mathrm{m}}$ generally declined, whereas OA increased it at LL $(17 \%$, post hoc: $p<0.01)$ or did not change it at ML. Noticeably, the interaction of HL and OA resulted in the lowest $F_{\mathrm{v}} / F_{\mathrm{m}}$ value. Comparing the $F_{\mathrm{v}} / F_{\mathrm{m}}$ measured before and after the FLC, the $F_{\mathrm{v}} / F_{\mathrm{m}}$ recovery

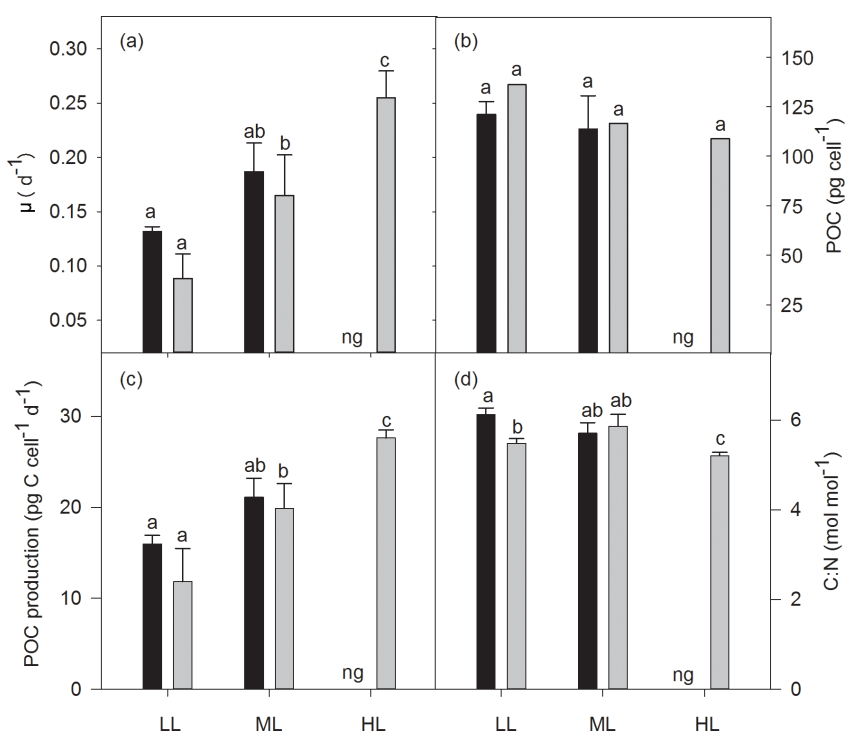

Figure 1. Growth rate (a), cellular content (b), and production rate (c) of particulate organic carbon (POC) and the molar ratio of carbon to nitrogen $(\mathrm{C}: \mathrm{N}, \mathbf{d})$ for Geminigera cryophila acclimated to ambient (black bars) or high $\mathrm{CO}_{2}$ (gray bars) conditions combined with low (LL), medium (ML) or high light (HL). G. cryophila did not grow under ambient $p \mathrm{CO}_{2}$ and $\mathrm{HL}$ as indicated by ng. Values represent the means $\pm \mathrm{SD}(n=3)$. Different letters indicate significant differences between treatments $(p<0.05)$.

Table 2. Cellular concentrations of chlorophyll $a$ and $c_{2}$ (Chl $a$ and $c_{2}$ ) as well as alloxanthin (Allo) were determined for Geminigera cryophila acclimated to ambient or high $\mathrm{CO}_{2}$ conditions combined with low (LL), medium (ML) or high light (HL). G. cryophila did not grow under ambient $p \mathrm{CO}_{2}$ and $\mathrm{HL}$ as indicated by ng. Photosynthetic parameters were derived from at least three independent measurements. Different letters indicate significant differences between treatments $(p<0.05)$. Values represent the means \pm SD Here, "fg" denotes femtogram.

\begin{tabular}{lrrr}
\hline Treatment & $\begin{array}{r}\mathrm{Chl} a \\
\left(\mathrm{fg} \mathrm{cell}^{-1}\right)\end{array}$ & $\begin{array}{r}\mathrm{Chl} c_{2} \\
\left(\mathrm{fg} \mathrm{cell}^{-1}\right)\end{array}$ & $\begin{array}{r}\text { Allo } \\
\left(\mathrm{fg} \mathrm{cell}^{-1}\right)\end{array}$ \\
\hline Ambient $p \mathrm{CO}_{2} \mathrm{LL}$ & $2358 \pm 277^{\mathrm{a}}$ & $172 \pm 33^{\mathrm{a}}$ & $81 \pm 3^{\mathrm{a}}$ \\
OA LL & $2300 \pm 25^{\mathrm{a}}$ & $131 \pm 1^{\mathrm{a}}$ & $60 \pm 2^{\mathrm{b}}$ \\
Ambient $p \mathrm{CO}_{2} \mathrm{ML}$ & $871 \pm 225^{\mathrm{b}}$ & $75 \pm 24^{\mathrm{b}}$ & $30 \pm 8^{\mathrm{c}}$ \\
OA ML & $662 \pm 22^{\mathrm{b}}$ & $48 \pm 15^{\mathrm{b}}$ & $27 \pm 3^{\mathrm{c}}$ \\
Ambient $p \mathrm{CO}_{2} \mathrm{HL}$ & $\mathrm{ng}$ & $\mathrm{ng}$ & $\mathrm{ng}$ \\
OA HL & $772 \pm 85^{\mathrm{c}}$ & $41 \pm 1^{\mathrm{b}}$ & $36 \pm 1^{\mathrm{d}}$ \\
\hline
\end{tabular}

was calculated and given as the percentage of the initial $F_{\mathrm{v}} / F_{\mathrm{m}}$. Neither high $p \mathrm{CO}_{2}$ nor the interaction of light and $\mathrm{CO}_{2}$ affected $F_{\mathrm{v}} / F_{\mathrm{m}}$ recovery, whereas the increase in irradiance had a significant effect (two-way ANOVA: $p<0.01$, Fig. 2b), being increased by $11 \%$ between LL and ML under ambient $p \mathrm{CO}_{2}$ (post hoc: $p<0.05$ ).

The increase in $\mathrm{CO}_{2}$ or light alone had no effect on cellular concentrations of functional photosystem II reaction centers 


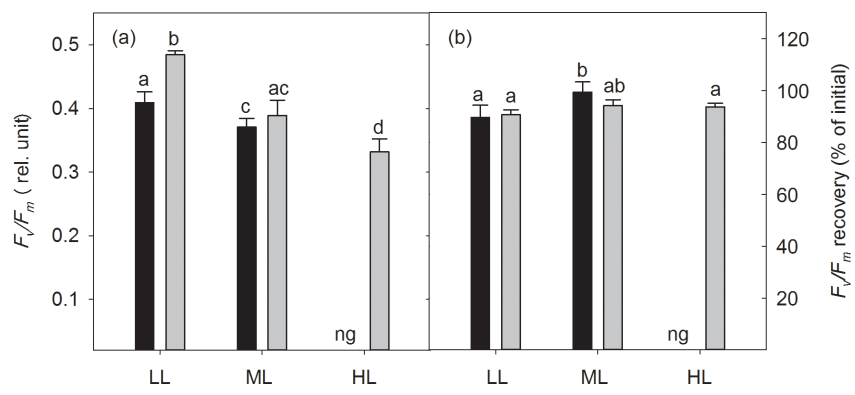

Figure 2. The dark-adapted maximum PSII quantum yield $F_{\mathrm{V}} / F_{\mathrm{m}}($ a) and the yield recovery after short-term light stress (\% of initial $\left.F_{\mathrm{V}} / F_{\mathrm{m}}\right)$ (b) for Geminigera cryophila acclimated to ambient (black bars) or high $\mathrm{CO}_{2}$ (gray bars) conditions combined with low (LL), medium (ML) or high light (HL). G. cryophila did not grow under ambient $p \mathrm{CO}_{2}$ and $\mathrm{HL}$ as indicated by ng. Values represent the means $\pm \mathrm{SD}(n=3)$. Different letters indicate significant differences between treatments $(p<0.05)$.

([RCII]), while the interaction of both factors strongly altered [RCII] (two-way ANOVA: $p<0.0001$; Fig. 3a). From LL to ML [RCII] decreased under ambient $p \mathrm{CO}_{2}(39 \%$, post hoc: $p<0.001$ ) while the combination of ML with OA synergistically increased it (44\%, post hoc: $p<0.01$, Fig. 3). [RCII] was reduced by OA at LL (37\% post hoc: $p<0.01)$, whereas the combined effect of OA and ML led to an increase $(49 \%$, post hoc: $p<0.01)$. While $\mathrm{CO}_{2}$ and the interaction of $\mathrm{CO}_{2}$ and light together did not change the energy transfer between PSII units (i.e., connectivity, $P$ ), only the increase in irradiance had a significant effect (two-way ANOVA: $p<0.05$ ), reducing $P$ by $22 \%$ between LL and ML under OA (post hoc: $p<0.05$, Fig. 3b). While the increase in $\mathrm{CO}_{2}$ or light did not alter the functional absorption cross sections of PSII ( $\left.\sigma_{\text {PSII }}\right)$, the interaction of both factors, however, had an effect (two-way ANOVA: $p<0.05$; Fig. $3 c) . \sigma_{\text {PSII }}$ values were similar under $\mathrm{LL}$ and $\mathrm{ML}$ at ambient $p \mathrm{CO}_{2}$. The interaction of OA and ML, however, lowered them (post hoc: $p<0.05$, Table 3). On the other hand, when grown under $\mathrm{OA} \sigma_{\mathrm{PSII}}$ was larger under HL than under ML (one-way ANOVA: $p<0.01$ ). Re-oxidation times of the primary electron acceptor $Q_{\mathrm{a}}\left(\tau_{Q_{\mathrm{a}}}\right)$ significantly changed with increasing irradiance (two-way ANOVA: $p<0.05$ ) but not with high $\mathrm{CO}_{2}$ or the interaction of both factors together (Fig. 3d). $\tau_{Q_{\mathrm{a}}}$ of OA-acclimated cells was much shorter at HL than at ML (one-way ANOVA: $p<0.05$ ).

Absolute ETRs differed in amplitude and shape in response to the applied changes in irradiance and $p \mathrm{CO}_{2}$ (Fig. 4a-c). Both maximum absolute electron transport rates $\left(E R_{\max }\right)$ and minimum saturating irradiances $\left(I_{k}\right)$ followed the same trend and were significantly changed by $\mathrm{CO}_{2}$ (twoway ANOVA: $p<0.05$ ) but not by light or the interaction of both factors (Table 3). OA significantly enhanced both parameters under LL $\left(\mathrm{ETR}_{\max }\right.$ : post hoc: $p<0.05 ; I_{k}$ : post hoc: $p<0.05)$ but not under ML. The maximum light uti-

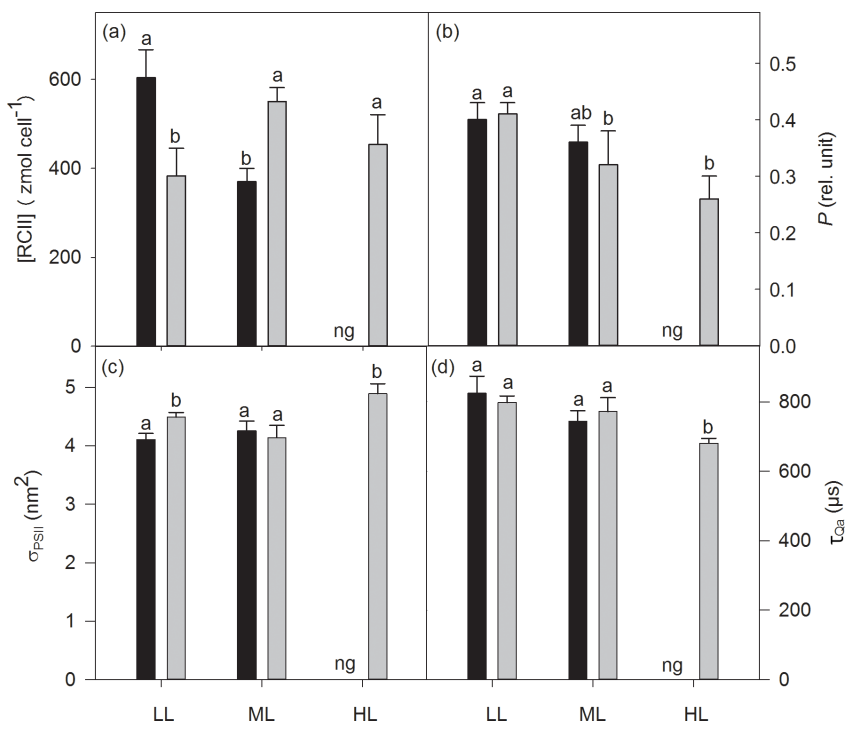

Figure 3. Cellular concentrations of functional photosystem II reaction centers $[\mathrm{RCII}]$ (a), energy transfers between PSII units (i.e., connectivity, $P$ ) (b), functional absorption cross sections of PSII photochemistry $\left(\sigma_{\mathrm{PSII}}\right)(\mathbf{c})$ and re-oxidation times of the primary electron acceptor $Q_{\mathrm{a}}\left(\tau_{Q_{\mathrm{a}}}\right)$ (d) were determined for Geminigera cryophila acclimated to ambient or high $\mathrm{CO}_{2}$ conditions combined with low (LL), medium (ML) or high light (HL). G. cryophila did not grow under ambient $p \mathrm{CO}_{2}$ and $\mathrm{HL}$ as indicated by ng. Different letters indicate significant differences between treatments $(p<0.05)$.

lization efficiency $(\alpha)$ was significantly affected by light (two-way ANOVA: $p<0.01$ ) and the interaction of $\mathrm{CO}_{2}$ and light (two-way ANOVA: $p<0.01$ ) but not by $\mathrm{CO}_{2}$ alone (Table 3). $\alpha$ significantly increased from LL to ML at ambient $p \mathrm{CO}_{2}(53 \%$, post hoc: $p<0.01)$ while such an effect was absent under ML and OA. Between ML and HL, $\alpha$ did not differ when grown under OA.

NPQ generally went up with increasing actinic irradiance during the FLC (Fig. 4d-f). Compared with the LL treatments, NPQ values of the ML and HL treatments were as twice as high. There were no differences in the NPQ pattern between the ML and HL treatments observed. Much higher NPQ values were determined in the ambient $p \mathrm{CO}_{2}$ relative to the $\mathrm{OA}$ treatment under LL while such a $p \mathrm{CO}_{2}$ effect was absent under ML.

\section{Discussion}

Ecophysiological studies on Antarctic cryptophytes to assess whether climatic changes such as ocean acidification and enhanced stratification affect their growth in Antarctic coastal waters in the future are lacking so far. This study can show that the Antarctic cryptophyte G. cryophila may be a potential winner of such climatic conditions as it reached the high- 
Table 3. Maximum absolute electron transport rates $\left(\mathrm{ETR}_{\max }\right)$, minimum saturating irradiances $\left(I_{k}\right)$ and maximum light utilization efficiencies $(\alpha)$ were determined for Geminigera cryophila acclimated to ambient or high $\mathrm{CO}_{2}$ conditions combined with low (LL), medium (ML) or high light (HL). G. cryophila did not grow under ambient $p \mathrm{CO}_{2}$ and $\mathrm{HL}$ as indicated by ng. Photosynthetic parameters were derived from at least three independent measurements. Different letters indicate significant differences between treatments $(p<0.05)$. Values represent the means $\pm \mathrm{SD}$.

\begin{tabular}{lrrr}
\hline Treatment & $\begin{array}{r}\mathrm{ETR}_{\max } \\
\left(\mathrm{e}^{-} \mathrm{PS}^{-1} \mathrm{~s}^{-1}\right)\end{array}$ & $\begin{array}{r}I_{k} \\
\left(\mu \mathrm{mol} \text { photons }{ }^{-2} \mathrm{~s}^{-1}\right)\end{array}$ & $\begin{array}{r}\alpha \\
(\text { rel. unit })\end{array}$ \\
\hline Ambient $p \mathrm{CO}_{2} \mathrm{LL}$ & $126 \pm 28^{\mathrm{a}}$ & $72 \pm 9^{\mathrm{a}}$ & $1.75 \pm 0.17^{\mathrm{a}}$ \\
OA LL & $279 \pm 52^{\mathrm{b}}$ & $142 \pm 34^{\mathrm{b}}$ & $1.98 \pm 0.11^{\mathrm{a}}$ \\
Ambient $p \mathrm{CO}_{2} \mathrm{ML}$ & $265 \pm 77^{\mathrm{b}}$ & $102 \pm 38^{\mathrm{b}}$ & $2.67 \pm 0.26^{\mathrm{b}}$ \\
OA ML & $278 \pm 70^{\mathrm{b}}$ & $138 \pm 48^{\mathrm{b}}$ & $2.06 \pm 0.24^{\mathrm{a}}$ \\
Ambient $p \mathrm{CO}_{2} \mathrm{HL}$ & $\mathrm{ng}$ & $\mathrm{ng}$ & $\mathrm{ng}$ \\
OA HL & $379 \pm 38^{\mathrm{b}}$ & $156 \pm 40^{\mathrm{b}}$ & $2.50 \pm 0.37^{\mathrm{a}}$ \\
\hline
\end{tabular}

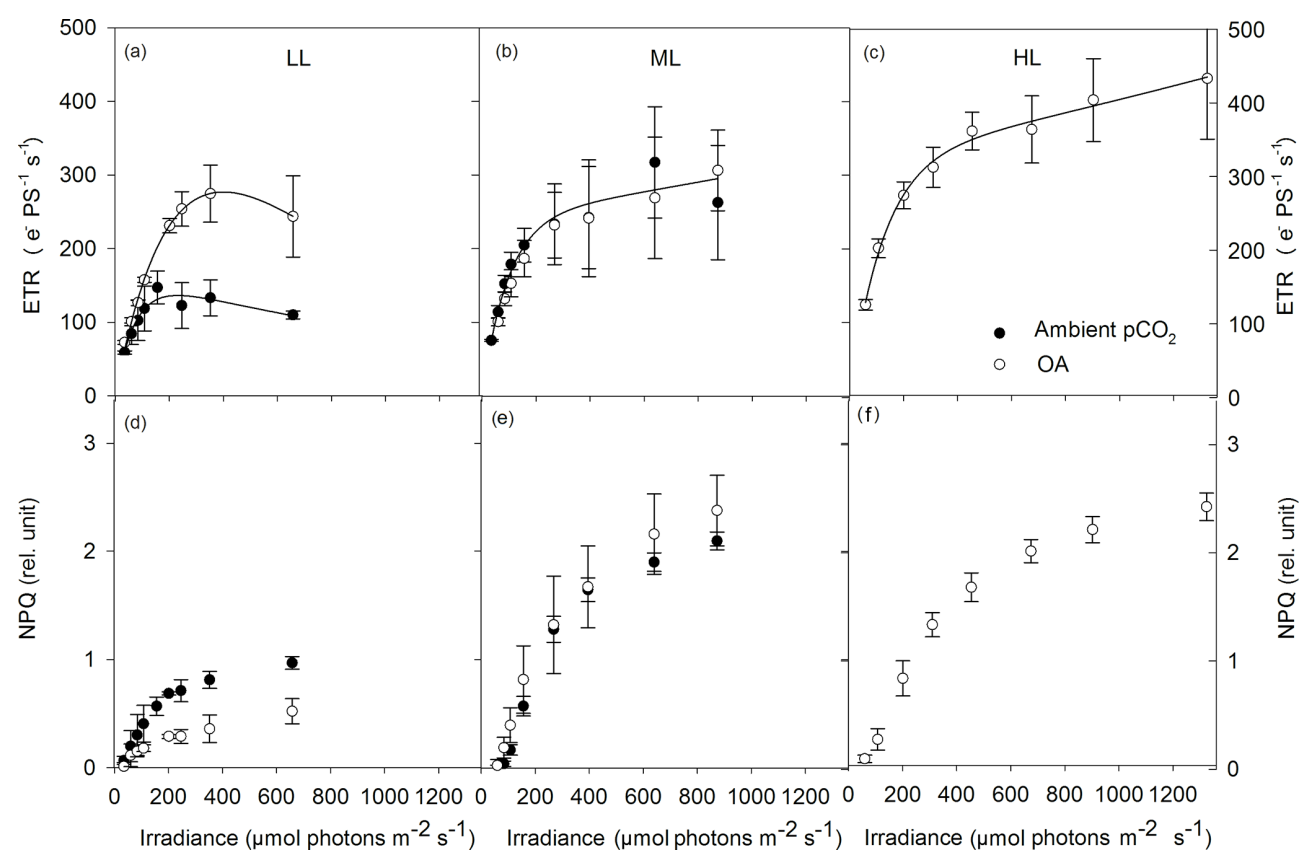

Figure 4. Absolute electron transport rates (ETR, a-c) and non-photochemical quenching (NPQ, d-f) were measured in response to increasing irradiance in Geminigera cryophila acclimated to ambient (black circles) or high $\mathrm{CO}_{2}$ (white circles) conditions combined with (a) low (LL), (b) medium (ML) or (c) high light (HL). G. cryophila did not grow under ambient $p \mathrm{CO}_{2}$ and HL. ETRs were obtained in three individual measurements. Values represent the means $\pm \operatorname{SD}(n=3)$.

est rates of growth and POC production when grown under $\mathrm{HL}$ and $\mathrm{OA}$.

\subsection{Geminigera cryophila is sensitive to increasing irradiance under ambient $p \mathrm{CO}_{2}$}

The cryptophyte G. cryophila was well adapted to grow under LL and ML at ambient $p \mathrm{CO}_{2}$, yielding similar growth, POC quotas and production rates as well as $\mathrm{C}: \mathrm{N}$ ratios (Fig. 1). In line with this, the exposure of the cryptophyte Rhodomonas salina to 30 up to $150 \mu \mathrm{mol}$ photons $\mathrm{m}^{-2} \mathrm{~s}^{-1}$ did not lead to any changes in growth rate at $5^{\circ} \mathrm{C}$ (Hammer et al., 2002). Even though growth and biomass remained un- changed in G. cryophila between LL and ML, acclimation to the even higher light intensity of $500 \mu \mathrm{mol}$ photons $\mathrm{m}^{-2} \mathrm{~s}^{-1}$ was indicated by the reduction in $F_{\mathrm{v}} / F_{\mathrm{m}}$ and [RCII] (Figs. 2a, 3a). Such a decline in the number of photosystems is a typical photo-acclimation response of most microalgae to increasing light and is usually accompanied by a decrease in cellular concentrations of light-harvesting pigments (MacIntyre et al., 2002), as seen here for cellular Chl $a$ and $c_{2}$ quotas (Table 2). Even though most studies on temperate cryptophytes report a photo-protective function of Allo, with higher amounts of this carotenoid toward high irradiance (Funk et al., 2011; Laviale and Neveux, 2011), the reduction in cellular Allo quotas from LL to ML in our 
tested species (Table 2) rather suggests its role in light absorption. Similarly, cellular Allo contents also declined between 40 and $100 \mu \mathrm{mol}$ photons $\mathrm{m}^{-2} \mathrm{~s}^{-1}$ in the temperate cryptophyte Rhodomonas marina (Henriksen et al., 2002). In this study, various photo-physiological parameters $(P$, $\sigma_{\mathrm{PSII}}, \tau_{Q_{\mathrm{a}}}$, Fig. 3) did not change between LL and ML in G. cryophila while other photo-acclimation processes such as higher $\mathrm{ETR}_{\max }, I_{k}$ and $\alpha$ took place (Table 3). Such a light-dependent, apparent higher electron flow was accompanied by similar high POC quotas and production rates between LL and ML (Fig. 1b, c) and suggests saturation of the Calvin cycle and therewith the requirement for alternative electron cycling to dissipate the excessive light energy. In the temperate $R$. salina, the onset of NPQ was induced after saturation of the Calvin cycle and was found to be located in the chlorophyll $a / c$ proteins and not in the phycobiliproteins (Kana et al., 2012). In fact, NPQ was strongly enhanced in G. cryophila between LL and ML at ambient $p \mathrm{CO}_{2}$ (Fig. 4). As ML-acclimated cells relative to LLacclimated ones also exhibited a higher potential of $F_{\mathrm{v}} / F_{\mathrm{m}}$ recovery after the FLC (Fig. 2b), it appears that all these adjustments allowed a reduction in the excitation pressure on the photosynthetic apparatus and protected G. cryophila well against short-term high light exposure. Unexpectedly, $G$. cryophila was, however, unable to grow at the highest light intensity of $500 \mu \mathrm{mol}$ photons $\mathrm{m}^{-2} \mathrm{~s}^{-1}$ under ambient $p \mathrm{CO}_{2}$, pointing towards its vulnerability of coping with $\mathrm{HL}$ under present-day $p \mathrm{CO}_{2}$. On the other hand, long-term field observations have shown that cryptophytes mainly occur under stratified conditions along the WAP (e.g., Moline and Prézelin, 1996; Moline et al., 2004; Mendes et al., 2013). A connection of this group with highly illuminated conditions was first suggested by Mendes et al. (2017), but this data set lacks information on which cryptophyte species were present and their photosynthetic responses. The reason for this difference could be related to species- or strain-specific differences. On the basis of our results, the G. cryophila strain tested here was indeed able to cope well with medium, but not high irradiances. More tests with other cryptophytes are certainly required to be able to better evaluate cryptophytes' abilities to cope with high irradiances.

\subsection{OA alters the physiological response of $G$. cryophila to high irradiance}

In line with previous studies on Antarctic diatoms and $P$. antarctica (Hoogstraten et al., 2012; Heiden et al., 2016; Trimborn et al., 2017b), OA in conjunction with low irradiance did not alter growth, cellular contents or production rates of POC in G. cryophila (Fig. 1a-c). There was, however, an OA-dependent decline in C : N under LL (Fig. 1d), resulting from a significant enhancement of PON quotas between ambient and high $p \mathrm{CO}_{2}(23.1 \pm 1.4$ and $29.0 \pm$ $1.6 \mathrm{pg} \mathrm{N} \mathrm{cell}^{-1}$, respectively). Hence, G. cryophila cells most probably benefitted from lower energy investments to ac- quire inorganic carbon under high $p \mathrm{CO}_{2}$. Whereas the two temperate cryptophytes Rhodomonas sp. and Chroomonas sp. (Burns and Beardall, 1987; Camiro-Vargas et al., 2005), similar to other Antarctic phytoplankton taxa (Trimborn et al., 2013), were able to actively take up $\mathrm{CO}_{2}$ and $\mathrm{HCO}_{3}^{-}$, the operation of a carbon concentrating mechanism in $G$. cryophila has not been tested so far. As typically observed for temperate phytoplankton (Hopkinson et al., 2011; McCarthy et al., 2012; Yang and Gao, 2012), the higher $p \mathrm{CO}_{2}$ was not used to fix more POC per cell by G. cryophila at LL (Fig. 1b, c) but instead fueled protein buildup through conversion of carbohydrate skeletons to proteins. $\mathrm{N}$ assimilation is energetically costly due to the reduction steps involved (Sanz-Luque et al., 2015); therefore, the finding of elevated PON buildup under OA and LL is surprising. In line with this, ETR $\mathrm{max}_{\max }$ per PSII increased by $121 \%$ from ambient to high $p \mathrm{CO}_{2}$ (Table 3), likely used to reduce nitrite to ammonium. Calculating overall maximum ETRs per cell $\left(\mathrm{cETR}_{\max }=\mathrm{ETR}_{\max } \times[\mathrm{RCII}]\right.$, given in amol cell ${ }^{-1} \mathrm{~s}^{-1}$ ), there was also an OA-dependent increase in cETR $_{\max }$ of $41 \%$ (mean value of 76 and $107 \mathrm{amol} \mathrm{cell}^{-1} \mathrm{~s}^{-1}$ under ambient and high $p \mathrm{CO}_{2}$, respectively), but this increase was comparably lower relative to ETR $_{\max }$ per PSII. The reason for this comes from the strong reduction in [RCII] between ambient and high $p \mathrm{CO}_{2}$ at LL (Fig. 3). Next to the positive OA effect on $\mathrm{N}$ metabolism, the photochemical efficiency $\left(F_{\mathrm{v}} / F_{\mathrm{m}}\right)$ of $G$. cryophila was also significantly increased by $17 \%$ by OA under LL (Fig. 2a). Unexpectedly, this effect was not the result of reduced cellular quotas of the light-harvesting pigments ( $\mathrm{Chl} a$ and $c_{2}$ ), as they remained the same under these conditions. Instead a significant OAdependent decrease of $26 \%$ in the carotenoid Allo was found (Table 2), which could explain the positive OA effect on $F_{\mathrm{v}} / F_{\mathrm{m}}$. This is in line with the OA-dependent reduction in NPQ observed in LL-acclimated G. cryophila cells (Fig. 4), pointing towards a reduced need to dissipate excess light energy following short-term high light exposure. Overall, OA in conjunction with LL was beneficial for G. cryophila, with positive effects in particular on $\mathrm{N}$ metabolism.

The beneficial OA effect on $\mathrm{N}$ assimilation under LL, however, vanished at ML (Fig. 1d; $23.2 \pm 3.2$ and $23.2 \pm$ $2.3 \mathrm{pgN}$ cell $^{-1}$ ), probably as a result of the higher $\mathrm{N}$ metabolism cost to maintain photosynthesis under these conditions ( $\mathrm{Li}$ et al., 2015). Based on our results, the physiology of the cryptophyte $G$. cryophila remained more or less unchanged between ambient and high $p \mathrm{CO}_{2}$ at ML (Figs. 1, 2, 4; Tables 2 and 3). At the highest irradiance (HL), G. cryophila could not grow under ambient $p \mathrm{CO}_{2}$, but surprisingly grew well under the same light intensity in conjunction with OA, displaying the highest growth rates compared to all other treatments (Fig. 1a). Similarly, this species also showed the highest production rates of POC and PON (Fig. 1). Compared with the Antarctic diatoms and P. antarctica tested so far, which exhibited either negative or neutral effects in response to OA and high irradiance on growth and/or photo- 
synthesis (Feng et al., 2010; Heiden et al., 2016, 2019; Trimborn et al., 2017a, b; Koch et al., 2019), growth and photosynthesis of the cryptophyte benefitted synergistically from $\mathrm{OA}$ and HL. Looking at the significantly higher amounts of Chl $a$ and Allo per cell and its larger $\sigma_{\text {PSII }}$ between ML and HL under OA (Table 2, Fig. 3c), this species even reinforced its capacity to absorb light. Faster electron drainage into downstream processes was evident by the shorter $Q_{\mathrm{a}}$ re-oxidation time between ML and HL under OA (Fig. 3d), supporting the idea that this species indeed managed to cope well with these conditions.

\subsection{Implications for the ecology of G. cryophila in future coastal Antarctic waters}

Along the coast of the WAP, diatoms, prymnesiophytes and cryptophytes represent the main phytoplankton groups, which form prominent blooms and therefore strongly contribute to carbon biomass buildup (Garibotti et al., 2005; Trimborn et al., 2015). The occurrence of cryptophytes in this region was associated with low salinity and warm stratified surface waters (Moline and Prézelin, 1996; Moline et al., 2004; Mendes et al., 2013, 2017). Only recently, it was suggested by Mendes et al. (2017) that a high tolerance of cryptophytes to withstand high irradiances could potentially explain their occurrence in well-illuminated surface waters. Our results from a short-term $\mathrm{CO}_{2}$ light experiment point towards a high ability of G. cryophila to acclimate to such conditions and to cope well with medium, but not high irradiances; whether this applies to other Antarctic cryptophyte species as well needs further testing. Also, it remains unclear whether similar responses would be found when exposed in the longer term. In general, with respect to the projected climatic changes little is known about the potential $\mathrm{CO}_{2}$ sensitivity of cryptophytes. Previous studies mainly assessed the response to OA of cryptophytes at the community level, and this showed no discernible effects on their abundance (Domingues et al., 2014; Sommer et al., 2015; Young et al., 2015; Schulz et al., 2017; Donahue et al., 2019). This study is the first at the species level to show that the combination of $\mathrm{OA}$ and high irradiance promoted growth and biomass production in the Antarctic cryptophyte G. cryophila. In fact, while HL conditions inhibited growth of this species under ambient $p \mathrm{CO}_{2}$, the combination of OA and $\mathrm{HL}$, on the other hand, enabled it to grow and to cope even better with the applied environmental conditions, reaching highest growth and POC production rates (Fig. 1). This was also accompanied with a high photo-physiological capacity of this species when exposed in the short term to increasing irradiances. The beneficial effect of OA and HL for G. cryophila is contrary to previous observations, where growth and/or photosynthesis were inhibited in several diatoms, but without any effect on the prymnesiophytes $P$. antarctica (Feng et al., 2010; Trimborn et al., 2017a, b; Beszteri et al., 2018; Heiden et al., 2018, 2019; Koch et al., 2018). Hence, G. cryophila could be a po- tential winner of climate change, with higher abundances and an increased contribution to the productivity of future stratified, acidified and well-illuminated coastal Antarctic waters. This study further confirms previous results (Moline et al., 2004; Ducklow et al., 2007; Montes-Hugo et al., 2009; Mendes et al., 2017), which point to a stronger importance of flagellates in the future. A functional shift away from efficient carbon sinkers such as diatoms to less efficient carbon vectors such as flagellates including cryptophytes and prymnesiophytes could, however, diminish the strength of the biological carbon pump of future Antarctic coastal waters.

Data availability. The raw data of this study are available in the PANGAEA data repository (https://doi.pangaea.de/10.1594/ PANGAEA.904010, Trimborn, 2019).

Author contributions. ScT designed the study. PK conducted the experiment. ScT, SiT and PK analyzed the data. ScT prepared the paper with contributions from SiT, PK and KB.

Competing interests. The authors declare that they have no conflict of interest.

Acknowledgements. Helen Soares de Souza, Jasmin P. Heiden, Tina Brenneis and Britta Meyer are thanked for the support in the laboratory. Scarlett Trimborn and Pascal Karitter were funded by the Helmholtz association (Young Investigator Group EcoTrace, VH-NG-901).

Financial support. This research has been supported by the Helmholtz Association (grant no. VH-NG-901).

The article processing charges for this open-access

publication were covered by a Research

Centre of the Helmholtz Association.

Review statement. This paper was edited by Emilio Marañón and reviewed by John Beardall and Marco J. Cabrerizo.

\section{References}

Arrigo, K. R., van Dijken, G., and Long, M.: Coastal Southern Ocean: A strong anthropogenic $\mathrm{CO}_{2}$ sink, Geophys. Res. Lett., 35, 1-6, https://doi.org/10.1029/2008GL035624, 2008.

Beszteri, S., Thoms, S., Benes, V., Harms, L., and Trimborn, S.: Acclimation to ocean acidification and high light in three Southern Ocean phytoplankton species: A transcriptomic study, Protist, 169, 958-975, https://doi.org/10.1016/j.protis.2018.08.003, 2018. 
Boelen, P., van de Poll, W. H., van der Strate, H. J., Neven, I. A., Beardall, J., and Buma, A. G. J.: Neither elevated nor reduced $\mathrm{CO}_{2}$ affects the photophysiological performance of the marine Antarctic diatom Chaetoceros brevis, J. Exp. Mar. Biol. Ecol., 406, 38-45, https://doi.org/10.1016/j.jembe.2011.06.012, 2011.

Burns, B. D. and Beardall, J.: Utilization of inorganic carbon by marine microalgae, J. Exp. Mar. Biol. Ecol., 107, 75-86, 1987.

Camiro-Vargas, T. K., Hernandez-Ayon, J. M., ValenzuelaEspinoza, E., Delgadillo-Hinojosa, F., and Cajal-Medrano, R.: Dissolved inorganic carbon uptake by Rhodomonas sp. and Isochrysis aff. galbana determined by a potentiometric technique, Aquacult. Eng., 33, 83-95, 2005.

Dickson, A. G. and Millero, F. J.: A comparison of the equilibrium constants for the dissociation of carbonic acid in seawater media, Deep-Sea Res., 34, 1733-1743, https://doi.org/10.1016/01980149(87)90021-5, 1987.

Domingues, R. B., Guerra, C. C., Barbosa, A. B., Brotas, V., Galvao, H. M., and Notes, A.: Effects of ultraviolet radiation and $\mathrm{CO}_{2}$ increase on winter phytoplankton assemblages in a temperate coastal lagoon, J. Plankton Res., 36, 672-684, https://doi.org/10.1093/plankt/fbt135, 2014.

Donahue, K., Klaas, C., Dillingham, P. W., and Hoffmann, L. J.: Combined effects of ocean acidification and increased light intensity on natural phytoplankton communities from two Southern Ocean water masses, J. Plankton Res., 41, 30-45, https://doi.org/10.1093/plankt/fby048, 2019.

Ducklow, H. W., Baker, K., Martinson, D. G., Quetin, L. B., Ross, R. M., Smith, R. C., Stammerjohn, R. C., Vernet, M., and Fraser, W.: Marine pelagic ecosystems: the West Antarctic Peninsula, Philos. T. R. Soc. B, 362, 67-94, 2007.

Ducklow, H. W., Fraser, W. R., Meredith, M. P., Stammerjohn, S. E., Doney, S. C., Martinson, D. G., Sailley, S. F., Schofield, O. M., Steinberg, D. K., Venables, H. J., and Amsler, C. D.: West Antarctic Peninsula: An ice-dependent coastal marine ecosystem in transition, Oceanography, 26, 190-203, https://doi.org/10.5670/oceanog.2013.62, 2013.

Falkowski, P. G. and Raven, J. A.: Aquatic Photosynthesis, Princeton University Press, Princeton, New Jersey, 501 pp., 2007.

Feng, Y., Hare, C. E., Rose, J. M., Handy, S. M., DiTullio, G. R., Lee, P. A., Smith, W. O., Peloquin, J., Tozzi, S., Sun, J., Zhang, Y., Dunbar, R. B., Long, M. C., Sohst, B., Lohan, M., and Hutchins, D. A.: Interactive effects of iron, irradiance and $\mathrm{CO}_{2}$ on Ross Sea phytoplankton, Deep-Sea Res. Pt. I, 57, 368-383, https://doi.org/10.1016/j.dsr.2009.10.013, 2010.

Fiala, M. and Oriol, L.: Light-temperature interactions on the growth of Antarctic diatoms, Polar Biol., 10, 629-36, 1990.

Funk, C., Alami, M., Tibiletti, T., and Green, B. R.: High light stress and the onehelix LHC-like proteins of the cryptophyte Guillardia theta, BBA-Bioenergetics, 1807, 841-846, 2011.

Garibotti, I. A., Vernet, M., and Ferrario, M. E.: Annually recurrent phytoplanktonic assemblages during summer in the seasonal ice zone west of the Antarctic Peninsula (Southern Ocean), Deep-Sea Res. Pt. I, 52, 1823-1841, https://doi.org/10.1016/j.dsr.2005.05.003, 2005.

Genty, B., Briantais, J.-M., and Baker, N. R.: The relationship between the quantum yield of photosynthetic electron transport and quenching of chlorophyll fluorescence, Biochim. Biophys. Acta, 990, 87-92, https://doi.org/10.1016/S03044165(89)80016-9, 1989.
Gould, S. B., Waller, R. F., and McFadden, G. I.: Plastid evolution, Annu. Rev. Plant Biol., 59, 491-517, 2008.

Guillard, R. R. L. and Ryther, J. H.: Studies of marine planktonic diatoms: I. Cyclotella nana Hustedt, and Detonula confervacea (Cleve), Gran., Can. J. Microbiol., 8, 229-239, https://doi.org/10.1139/m62-029, 1962.

Hammer, A., Schumann, R., and Schubert, H.: Light and temperature acclimation of Rhodomonas salina (Cryptophyceae): Photosynthetic performance, Aquat. Microb. Ecol., 29, 287-296, https://doi.org/10.3354/ame029287, 2002.

Heiden, J. P., Bischof, K., and Trimborn, S.: Light intensity modulates the response of two Antarctic diatom species to ocean acidification, Front. Mar. Sci., 3, 260, https://doi.org/10.3389/fmars.2016.00260, 2016.

Heiden, J. P., Thoms, S., Bischof, K., and Trimborn, S.: Ocean acidification stimulates particulate organic carbon accumulation in two Antarctic diatom species under moderate and high solar radiation, J. Phycol., 54, 505-517, https://doi.org/10.1111/jpy.12753, 2018.

Heiden, J. P., Völkner, C., Jones, E., Van de Poll, W. H., Buma A. G. J., Meredith, M. P., De Baar, H., Bischof, K., Wolf-Gladrow, D., and Trimborn, S.: Impact of ocean acidification and high solar radiation on productivity and species composition of a late summer phytoplankton community of the coastal Western Antarctic Peninsula, Limnol. Oceanogr., https://doi.org/10.1002/lno.11147, online first, 2019.

Henriksen, P., Riemann, B., Sorensen, H. M., and Sorensen, H. L.: Effects of nutrient-limitation and irradiance on marine phytoplankton pigments, J. Plankton Res., 24, 835-858, 2002.

Hoogstraten, A., Timmermans, K. R., and de Baar, H. J. W.: Morphological and physiological effects in Proboscia Alata (Bacillariophyceae) grown under different light and $\mathrm{CO}_{2}$ conditions of the modern Southern Ocean, J. Phycol., 48, 559-568, https://doi.org/10.1111/j.1529-8817.2012.01148.x, 2012.

Hopkinson, B. M., Dupont, C. L., Allen, A. E., and Morel, F. M. M.: Efficiency of the $\mathrm{CO}_{2}$-concentrating mechanism of diatoms, P. Natl. Acad. Sci. USA, 108, 3830-3837, 2011.

Hoppe, C. J. M., Holtz, L., Trimborn, S., and Rost, B.: Ocean acidification decreases the light-use efficiency in an Antarctic diatom under dynamic but not constant light, New Phytol., 207, 159171, https://doi.org/10.1111/nph.13334, 2015.

Kana, R., Kotabova, E., Sobotka, R., and Prasil, O.: Nonphotochemical quenching in cryptophyte alga Rhodomonas salina is located in chlorophyll $a / c$ antennae, PLoS ONE, 7, e29700, https://doi.org/10.1371/journal.pone.0029700, 2012.

Koch, F., Beszteri, S., Harms, L., and Trimborn, S.: The impacts of iron limitation and ocean acidification on the cellular stoichiometry, photophysiology and transcriptome of Phaeocystis antarctica, Limnol. Oceanogr., 64, 357-375, https://doi.org/10.1002/lno.11045, 2018.

Kolber, Z. S., Prášil, O., and Falkowski, P. G.: Measurements of variable chlorophyll fluorescence using fast repetition rate techniques: Defining methodology and experimental protocols, Biochim. Biophys. Acta, 1367, 88-106, https://doi.org/10.1016/S0005-2728(98)00135-2, 1998.

Laviale, M. and Neveux, J.: Relationships between pigment ratios and growth irradiance in 11 marine phytoplankton species, Mar. Ecol.-Prog. Ser., 425, 63-77, https://doi.org/10.3354/meps09013, 2011. 
Li, G., Brown, C. M., Jeans, J. A., Donaher, N. A., McCarthy, A., and Campbell, D. A.: The nitrogen costs of photosynthesis in a diatom under current and future $p \mathrm{CO}_{2}$, New Phytol., 205, 533543, https://doi.org/10.1111/nph.13037, 2015.

MacIntyre, H. L., Kana, T. M., Anning, T., and Geider, R. J.: Photoacclimation of photosynthesis irradiance response curves and photosynthetic pigments in microalgae and cyanobacteria, J. Phycol., 38, 17-38, https://doi.org/10.1046/j.15298817.2002.00094.x, 2002.

McCarthy, A., Rogers, S. P., Duffy, S. J., and Campbell, D. A.: Elevated carbon dioxide differentially alters the photophysiology of Thalassiosira pseudonana (Bacillariophyceae) and Emiliania huxleyi (Haptophyta), J. Phycol., 48, 635-646, 2012.

Mehrbach, C., Culberson, C. H., Hawley, J. E., and Pytkowicz, R. M.: Measurement of the apparent dissociation constants of carbonic acid in seawater at atmospheric pressure, Limnol. Oceanogr., 18, 897-907, https://doi.org/10.4319/lo.1973.18.6.0897, 1973.

Mendes, C. R. B., Tavano, V. M., Leal, M. C., de Souza, M. S., Brotas, V., and Garcia, C. A. E.: Shifts in the dominance between diatoms and cryptophytes during three late summers in the Bransfield Strait (Antarctic Peninsula), Polar Biol., 36, 537-547, https://doi.org/10.1007/s00300-012-1282-4, 2013.

Mendes, C. R. B., Tavano, V. M., Dotto, T. S., Kerr, R., De Souza, M. S., Garcia, C. A. E., and Secchi, E. R.: New insights on the dominance of cryptophytes in Antarctic coastal waters: A case study in Gerlache Strait, Deep-Sea Res. Pt. II, 149, 161-170, https://doi.org/10.1016/j.dsr2.2017.02.010, 2017.

Moline, M. A. and Prézelin, B. B.: Long-term monitoring and analyses of physical factors regulating variability in coastal Antarctic phytoplankton biomass, in situ productivity and taxonomic composition over seasonal and interannual timescales, Mar. Ecol.Prog. Ser., 145, 143-160, https://doi.org/10.3354/Meps145143, 1996.

Moline, M. A., Claustre, H., Frazer, T. K., Schofield, O., and Vernet, M.: Alteration of the food web along the Antarctic Peninsula in response to a regional warming trend, Glob. Change Biol., 10, 1973-1980, https://doi.org/10.1111/j.13652486.2004.00825.x, 2004.

Montes-Hugo, M., Doney, S. C., Ducklow, H. W., Fraser, W. R., Martinson, D. G., Stammerjohn, S. E., and Schofield, O.: Recent changes in phytoplankton communities associated with rapid regional climate change along the western Antarctic Peninsula, Science, 323, 1470-1473, https://doi.org/10.1126/science.1164533, 2009.

Moreau, S., Mostajir, B., Bélanger, S., Schloss, I. R., Vancoppenolle, M., Demers, S., and Ferreyra, G. A.: Climate change enhances primary production in the western Antarctic Peninsula, Glob. Change Biol., 21, 2191-2205, https://doi.org/10.1111/gcb.12878, 2015.

Orr, J. C., Fabry, V. J., Aumont, O., Bopp, L., Doney, S. C., Feely, R. A., Gnanadesikan, A., Gruber, N., Ishida, A., Joos, F., Key, R. M., Lindsay, K., Maier-Reimer, E., Matear, R., Monfray, P., Mouchet, A., Najjar, R. G., Plattner, G.-K., Rodgers, K. B., Sabine, C. L., Sarmiento, J. L., Schlitzer, R., Slater, R. D., Totterdell, I. J., Weirig, M.-F., Yamanaka, Y., and Yool, A.: Anthropogenic ocean acidification over the twenty-first century and its impact on calcifying organisms, Nature, 437, 681-686, 2005.
Oxborough, K., Moore, C. M., Suggett, D. J., Lawson, T., Chan, H. G., and Geider, R. J.: Direct estimation of functional PSII reaction center concentration and PSII electron flux on a volume basis: a new approach to the analysis of Fast Repetition Rate fluorometry (FRRf) data, Limnol. Oceanogr.-Meth., 10, 142-154, https://doi.org/10.4319/lom.2012.10.142, 2012.

Pachauri, R. K. and Meyer, L. A. (Eds.): Climate Change 2014: Synthesis Report., ed. Contribution of workinggroups I, II and III to the fifth assessment report of the intergovernmental panel on climate change, Geneva, Switzerland, 2014.

Pierrot, D., Lewis, E., and Wallace, D. W. R.: MS Excel Program Developed for $\mathrm{CO}_{2}$ System Calculations, ORNL/CDIAC-105a, Carbon Dioxide Information Analysis Center, Oak Ridge National Laboratory, U.S. Department of Energy, Oak Ridge, Tennessee, https://doi.org/10.3334/CDIAC/otg.CO2SYS_XLS_CDIAC105a, 2006.

Ralph, P. J. and Gademann, R.: Rapid light curves: A powerful tool to assess photosynthetic activity, Aquat. Bot., 82, 222-237, https://doi.org/10.1016/j.aquabot.2005.02.006, 2005.

Redfield, A. C.: The biological control of chemical factors in the environment, Am. Sci., 64, 205-221, 1958.

Riebesell, U., Wolf-Gladrow, D. A., and Smetacek, V.: Carbon dioxide limitation of marine phytoplankton growth rates, Nature, 361, 249-251, 1993.

Rozema, P. D., Venables, H. J., van de Poll, W. H., Clarke, A., Meredith, M. P., and Buma, A. G. J.: Interannual variability in phytoplankton biomass and species composition in northern Marguerite Bay (West Antarctic Peninsula) is governed by both winter sea ice cover and summer stratification, Limnol. Oceanogr., 62, 235-252, 2017.

Sanz-Luque, E., Chamizo-Ampudia, A., Llamas, A., Galvan, A., and Fernandez, E.: Understanding nitrate assimilation and its regulation in microalgae, Front. Plant Sci., 6, 899, https://doi.org/10.3389/fpls.2015.00899, 2015.

Schulz, K. G., Bach, L. T., Bellerby, R. G. J., Bermúdez, R., Büdenbender, J., Boxhammer, T., Czerny, J., Engel, A., Ludwig, A., Meyerhöfer, M., Larsen, A., Paul, A. J., Sswat, M., and Riebesell, U.: Phytoplankton blooms at increasing levels of atmospheric carbon dioxide: Experimental evidence for negative effects on prymnesiophytes and positive on small picoeukaryotes, Front. Mar. Sci., 4, 64, https://doi.org/10.3389/fmars.2017.00064, 2017.

Smith, R. C. and Stammerjohn, S. E.: Variations of surface air temperature and sea-ice extent in the western Antarctic Peninsula region, Ann. Glaciol., 33, 493-500, https://doi.org/10.3189/172756401781818662, 2001.

Sommer, U., Paul, C., and Moustaka-Gouni, M.: Warming and ocean acidification effects on phytoplankton - From species shifts to size shifts within species in a mesocosm experiment, PLoS ONE, 10, e0125239, https://doi.org/10.1371/journal.pone.0125239, 2015.

Stoll, M. H. C., Bakker, K., Nobbe, G. H., and Haese, R. R. Continous-flow analysis of dissolved inorganic carbon content in seawater, Anal. Chem., 73, 4111-4116, https://doi.org/10.1021/ac010303r, 2001.

Suggett, D. J., MacIntyre, H. L., and Geider, R. J.: Evaluation of biophysical and optical determinations of light absorption by 
photosystem II in phytoplankton, Limnol. Oceanogr.-Meth., 2, 316-332, https://doi.org/10.4319/lom.2004.2.316, 2004.

Suggett, D. J., Moore, C. M., Hickman, A. E., and Geider, R. J.: Interpretation of fast repetition rate (FRR) fluorescence: Signatures of phytoplankton community structure versus physiological state, Mar. Ecol.-Prog. Ser., 376, 1-19, https://doi.org/10.3354/meps07830, 2009.

Trimborn, S.: Ocean acidification and high irradiance stimulate the photo-physiological fitness, growth and carbon production of the Antarctic cryptophyte Geminigera cryophila, PANGAEA, https://doi.org/10.1594/PANGAEA.904010, 2019.

Trimborn, S., Brenneis, T., Sweet, E., and Rost, B.: Sensitivity of Antarctic phytoplankton species to ocean acidification: growth, carbon acquisition and species interaction, Limnol. Oceanogr., 58, 997-1007, 2013.

Trimborn, S., Hoppe, C. J. M., Taylor, B., Bracher, A., and Hassler, C.: Physiological characteristics of phytoplankton communities of Western Antarctic Peninsula and Drake Passage waters, DeepSea Res. Pt. I, 98, 115-124, 2015.

Trimborn, S., Brenneis, T., Hoppe, C. J. M., Norman, L., Santos, J., Laglera, L., Völkner, C., Wolf-Gladrow, D., and Hassler, C.: Iron sources alter the response of Southern Ocean phytoplankton to ocean acidification, Mar. Ecol.-Prog. Ser., 578, 35-50, https://doi.org/10.3354/meps12250, 2017a.
Trimborn, S., Thoms, S., Brenneis, T., Heiden, J. P., Beszteri, S., and Bischof, K.: Two Southern Ocean diatoms are more sensitive to ocean acidification and changes in irradiance than the prymnesiophyte Phaeocystis antarctica, Physiol. Plant., 160, 155-170, https://doi.org/10.1111/ppl.12539, 2017b.

Wright, S. W., Jeffrey, S. W., Mantoura, R. F. C., Llewellyn, C. A., Bjornland, T., Repeta, D., and Welschmeyer, N.: Improved HPLC method for the analysis of chlorophylls and carotenoids from marine phytoplankton, Mar. Ecol.-Prog. Ser., 77, 183-196, https://doi.org/10.3354/meps077183, 1991.

Yang, G. and Gao, K.: Physiological responses of the marine diatom Thalassiosira pseudonana to increased $p \mathrm{CO}_{2}$ and seawater acidity, Mar. Environ. Res., 79, 142-151, https://doi.org/10.1016/j.marenvres.2012.06.002, 2012.

Young, J. N., Kranz, S. A., Goldman, J. A. L., Tortell, P. D., and Morel, F. M. M.: Antarctic phytoplankton down-regulate their carbon-concentrating mechanisms under high $\mathrm{CO}_{2}$ with no change in growth rates, Mar. Ecol.-Progr. Ser., 532, 13-28, 2015. 